\title{
Tension type headache is dead; long live chronic migraine!
}

\author{
GE Elrington \\ From The European Headache and Migraine Trust International Congress \\ London, UK. 20-23 September 2012
}

Chronic Migraine (CM) was first defined in 2004. The definition was revised in 2006[1]. The definition allows occurence of both migraine and tension-type headache (TTH). This study analyses the Introduction of the new diagnosis of $\mathrm{CM}$ in one neurologist's practice. A patient database for all patients seen in consultation has been maintained since 1994. Total patient numbers are currently over 22,000. Data are collected and recorded at the time of first consultation and updated when the patient is reviewed. All relevant diagnoses are recorded; patients often have more than one diagnosis. Before the definition of CM, patients with other primary headache, and medication overuse headache $(\mathrm{MOH})$, were diagnosed with both the primary headache, and $\mathrm{MOH}$, when appropriate. This practice continued when coding for $\mathrm{CM}$, despite the IHS definition excluding $\mathrm{CM}$ in $\mathrm{MOH}$ patients. A steady rise in CM since 2004 has peaked at about 150 cases a year. This is mirrored by a fall in diagnosis of TTH to single figures annually. It is likely that patients with chronic headache,formerly diagnosed as both TTH and migraine, can now receive a single diagnosis of CM. CM has proved common in this practice and has largely superceded the diagnosis of TTH.

\section{Competing interests}

The author has worked with most of not all of the pharma industry, including Allergan for whom he was a triallist in the PREEMPT study, and member of advisory boards.

Published: 21 February 2013

\section{Reference}

1. Headache Classification Committee, Olesen J, Bousser M-G, Diener H-C, Dodick D, First M, Goadsby PJ, Göbel H, Lainez MJA, Lance JW, Lipton RB,

Nappi G, Sakai F, Schoenen J, Silberstein SD, Steiner TJ: New appendix criteria open for a broader concept of chronic migraine. Cephalalgia 2006, 26:742-746.
doi:10.1186/1129-2377-14-S1-P48

Cite this article as: Elrington: Tension type headache is dead; long live chronic migraine!. The Journal of Headache and Pain 2013 14(Suppl 1):P48.
Submit your manuscript to a SpringerOpen ${ }^{\circ}$ journal and benefit from:

- Convenient online submission

- Rigorous peer review

- Immediate publication on acceptance

- Open access: articles freely available online

- High visibility within the field

- Retaining the copyright to your article

Submit your next manuscript at $\boldsymbol{~ s p r i n g e r o p e n . c o m ~}$ 